\title{
Toxin to medicine and bioisosterism in drug development: a study of the discovery and development of ACE inhibitors from snake venom
}

\author{
Akolade R. Oladipupo* \\ Department of Pharmaceutical Chemistry, Faculty of Pharmacy, University of Lagos, \\ College of Medicine Campus, PMB 12003, Idi-araba, Lagos, Nigeria
}

Received: September 2020; Accepted: December 2020

\begin{abstract}
The advent of the angiotensin-converting enzyme (ACE) inhibitors is a landmark in drug discovery and a breakthrough in the management of hypertension. Their clinical introduction has led to appreciable increase in the lifespan of hypertensive patients. And their development initiated a new era of structure-based or rational drug design that has subsequently been applied successfully for development of drugs for many other disorders. This paper presents an account of the discovery, design and development of ACE inhibitors from an academic perspective and possibly, as a guide to future research. The paper highlights the milestones and recounts the challenges encountered and the strategies applied in the search for ACE inhibitors. This exposition also expounds some of the concepts and intricacies of drug discovery, design and development.
\end{abstract}

Keywords: drug development, ACE inhibitors, snake venom peptide, bioisosterism, antihypertensive agents

\section{Introduction}

The ACE inhibitors are an important group of drugs that are used in the treatment of hypertension, congestive heart failure, and chronic kidney disease (Jackson, 2006). They inhibit ACE, an important component of the reninangiotensin system (RAS), which controls blood pressure by regulating arterial vasoconstriction and extracellular fluid volume (Byrd et al., 2019). ACE converts angiotensin I to the vasoconstrictor angiotensin II and inactivates the vasodilator bradykinin. Inhibition of ACE leads to decrease in blood volume and dilation of blood vessels, which results with decrease in blood pressure, helping to control hypertension. The advent of the ACE inhibitors is a landmark in drug discovery and a breakthrough in the management of hypertension. Their

\footnotetext{
* oladipupoakolade@gmail.com
}

clinical introduction has led to appreciable increase in the lifespan of hypertensive patients (Borer, 2007). The discovery and development of ACE inhibitors entailed series of long and arduous projects spanning almost a century, from the inception of the discovery of the reninangiotensin system in 1898 to the observation and isolation of hypotensive peptides from Brazilian pit viper's venom to the extensive structural modifications that led to the discovery and introduction of captopril, a first-in-class, orally active ACE inhibitor, in 1981. In this paper, an account of the discovery, design and development of ACE inhibitors is given, from an academic perspective and, possibly, as a guide to future research. The paper highlights the milestones and recounts the challenges encountered and the strategies applied in the search for ACE inhibitors. In this exposition, some of the concepts and intricacies of drug discovery, design and development are also expound. 


\section{Bioisosteric considerations in drug development}

Drug discovery, design and development is a capital and labour intensive process that involves a complex interaction between academia, industry, investors and regulatory authorities. It is hardly an orderly or predictable process. However, it often begins with the search for new lead compounds. A lead compound is a compound of therapeutic interest whose chemical structure is used as a starting point for chemical modifications to achieve favourable pharmacological properties. Optimization of a lead compound to fulfil the desired therapeutic effect is a key step in drug development process and presents considerable challenge to medicinal chemists. Lead optimization entails identifying the core structure(s) of a lead compound and making defined changes to its functional groups or substituents to test specific hypotheses. A typical lead compound often possesses multiple modification points and the number of feasible alternative groups at each point could be high; making the potential molecules that could be synthesized very high. Therefore, the question of which molecules to synthesize and test is of great import. The concept of bioisosterism is a rational and strategic approach to efficiently explore and exploit the possible options to this question. This has been further expanded and made easier by the availability of facile computational methods.

Bioisosterism is the application of isosterism to the design of bioactive molecules. The concept of isosterism was formulated in 1919 by Irving Langmuir (awarded the Nobel Prize in Chemistry in 1932). He defined isosteres or isosteric compounds as compounds or groups of atoms that possess the same number and/or arrangement of electrons e.g. $\mathrm{N}_{2}$ and $\mathrm{C}=\mathrm{O} ; \mathrm{CH}_{4}$ and $\mathrm{NH}_{4}{ }^{+} ; \mathrm{Cl}^{-}, \mathrm{K}^{+}$and $\mathrm{Ca}^{2+}$; etc. (Langmuir, 1919). In his seminal paper "Isomorphism, isosterism and covalence", Langmuir noted the remarkable similarities in physical properties of isosteres. The concept of isosterism was broadened in 1925 by the introduction of Grimm's hydride displacement law which profers that addition of a hydrogen atom to another atom results into a pseudoatom of the next atom on the periodic table (Table 1) (Grimm, 1925).

Table 1. Grimm's hydride displacement law

\begin{tabular}{lllllll}
\hline \hline \multicolumn{7}{c}{ Number of electrons } \\
& 6 & 7 & 8 & 9 & 10 & 11 \\
& $\mathrm{C}$ & $\mathrm{N}$ & $\mathrm{O}$ & $\mathrm{F}$ & $\mathrm{Ne}$ & $\mathrm{Na}^{+}$ \\
Pseudoatoms: & & $\mathrm{CH}$ & $\mathrm{NH}$ & $\mathrm{OH}$ & $\mathrm{FH}$ & - \\
& & & $\mathrm{CH}_{2}$ & $\mathrm{NH}_{2}$ & $\mathrm{OH}_{2}$ & $\mathrm{FH}_{2}{ }^{+}$ \\
& & & & $\mathrm{CH}_{3}$ & $\mathrm{NH}_{3}$ & $\mathrm{OH}_{3}{ }^{+}$ \\
& & & & $\mathrm{CH}_{4}$ & $\mathrm{NH}_{4}{ }^{+}$ \\
\hline
\end{tabular}

With this expansion, $\mathrm{CH}$ and $\mathrm{N} ; \mathrm{CH}_{2}, \mathrm{NH}$, and $\mathrm{O}$, etc. are isosteres: they have similar electrosteric and physical properties. Erlenmeyer and Leo (1932) further broadened Grimm's classification and redefined isosteres as elements, molecules or ions in which the peripheral layers of electrons may be considered identical (Table 2).

Table 2. Isosteres based on the number of peripheral electrons

\begin{tabular}{lllll}
\hline \multicolumn{5}{l}{ Number of peripheral electrons } \\
\hline 4 & 5 & 6 & 7 & 8 \\
$\mathrm{~N}^{+}$ & $\mathrm{P}$ & $\mathrm{S}$ & $\mathrm{Cl}$ & $\mathrm{ClH}$ \\
$\mathrm{P}^{+}$ & $\mathrm{As}$ & $\mathrm{Se}$ & $\mathrm{Br}$ & $\mathrm{BrH}$ \\
$\mathrm{S}^{+}$ & $\mathrm{Sb}$ & $\mathrm{Te}$ & $\mathrm{I}$ & $\mathrm{IH}$ \\
$\mathrm{As}^{+}$ & & $\mathrm{PH}$ & $\mathrm{SH}$ & $\mathrm{SH}_{2}$ \\
$\mathrm{Sb}^{+}$ & & & $\mathrm{PH}_{2}$ & $\mathrm{PH}_{3}$ \\
\hline
\end{tabular}

In addition, Erlenmeyer and Leo (1932) notably proposed the concept of ring equivalences to include isosteric matches between different ring systems. The concept of isosterism has been further developed by a number of scientists, notably, Friedman (1951), Thornber (1979) and Burger (1991). The application of isosterism in medicinal chemistry led to the concept of bioisosterism.

Bioisosteres are substituents or groups with similar chemical and physical properties that produce similar biological properties (Thornber, 1979; with slight modification). The appropriate application of isosterism in drug development demands careful analysis of the physical, chemical, electronic and conformational parameters involved in the planned bioisosteric replacement, so as to predict, although theoretically, any eventual alterations in terms of the pharmacodynamic and pharmacokinetic properties which the new isosteric substituent presents (Lima and Barreiro, 2005). As further noted by Lima and Barreiro (2005), certain isosteric substituents could dramatically alter the physicochemical and electrosteric properties of molecular candidates and, consequently, their activities. This can be understood by considering the bioisosteric transformation resulting from isosteric replacement of hydroxyl $(-\mathrm{OH})$ with amine ($\mathrm{NH}_{2}$ ), which is an example of classic isosterism of monovalent groups according to Grimm's law. Specifically, considering the bioisosteric replacement of aromatic hydroxyl present in phenol (Fig. 1a) with amine, we have aniline (Fig. 1b) resulting in a significant change in the acid-base properties of the molecule, with dramatic modification of the $\mathrm{pKa}$, which may consequently alter the pharmacokinetic profile of the molecule in question. In addition, with regard to molecular recognition of and interaction with a given receptor site, there is a change from a negatively charged acidic phenoxide moiety $\left(\mathrm{Ph}-\mathrm{O}^{-}\right.$ , $\mathrm{pKa}=10.0)$ to a positively charged basic anilinium moiety $\left(\mathrm{Ph}-\mathrm{NH}^{3+}, \mathrm{pKb}=9.30\right)$, which may, quite probably, abolish the original activity (Barreiro and Fraga, 2001). Thus, pure isosteric exchange is often not feasible in drug design. 
<smiles>Oc1ccccc1</smiles>

(a)<smiles>CNCC(O)c1ccc(O)cc1</smiles>

(c)<smiles>Nc1ccccc1</smiles>

(b)
Pure isosteric exchange, but alteration of activity. Thus, incorrect bioisosterism

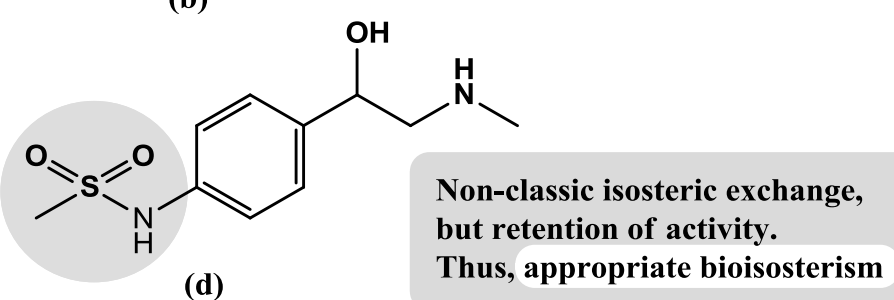

Fig. 1. Isosterism and bioisosterism.

Furthermore, it has been shown that groups that do not contain the same number of atoms nor possess similar electrosteric properties could exhibit the same biological properties. A classic example of this is found in the replacement of the phenolic hydroxyl group in the adrenergic alkaloid, synephrine (Fig. 1c) with an alkyl sulfonamide group. The resulting compound (Fig. 1d) showed comparable biological activity to synephrine (Larsen and Lish, 1964), which indicates that both functional groups involved are appropriate bioisosteres for the molecule and molecular target in question. These and similar findings have led to the classification of bioisosteres as classical and non-classical bioisosteres (Burger, 1970).
Classical bioisosteres are atoms or molecular units that have similar steric and electronic properties. These encompass (a) monovalent atoms or groups, (b) divalent atoms or groups, (c) trivalent atoms or groups, (d) tetravalent atoms and (e) ring equivalents (Table 3).

Non-classical bioisosteres are atoms or molecular units that are structurally distinct, usually comprise different number of atoms and exhibit different steric and electronic properties. These include (a) cyclic or acyclic isosteres, (b) exchangeable functional groups isosteres and (c) retroisosterism - inversion of a defined functional group present in the lead molecule to produce an isostere with the same function (Fig. 2). Non-classical bioisosterism are predominantly used in contemporary drug design.

Table 3. Examples of classical bioisosteres

\begin{tabular}{lllll}
\hline \hline Monovalent & Divalent & Trivalent & Tetravalent & Ring equivalents \\
\hline $\mathrm{F}$ and $\mathrm{H}$ & $-\mathrm{C}=\mathrm{C}-,-\mathrm{C}=\mathrm{N}$ & $=\mathrm{CH}-$ & $\mathrm{R}_{4} \mathrm{~N}^{+}$ & Benzene, pyridine, \\
$\mathrm{NH}_{2}$ and $\mathrm{OH}$ & $-\mathrm{C}=\mathrm{O},-\mathrm{C}=\mathrm{S}$ & $=\mathrm{N}-$ & $\mathrm{R}_{4} \mathrm{C}$ & thiophene, furan \\
$\mathrm{F}, \mathrm{NH}_{2}$ and $\mathrm{CH}_{3}$ & $-\mathrm{CH}_{2}-,-\mathrm{NH}-$ & $=\mathrm{P}-$ & $\mathrm{R}_{4} \mathrm{Si}$ & THF, pyrrolidine \\
$\mathrm{Cl}, \mathrm{Br}, \mathrm{SH}$ and $\mathrm{OH}$ & $-\mathrm{O}-,-\mathrm{S}-$ & $=\mathrm{As}-$ & & tetrahydrothiophene \\
\hline
\end{tabular}

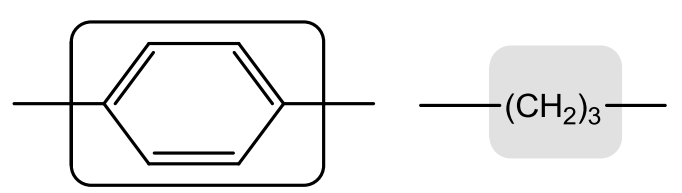

(a: cyclic or acyclic isosteres)

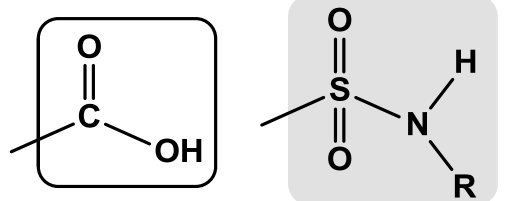

(b: functional groups isosteres)<smiles>[R]C1CCCCC1[R]</smiles><smiles>C1=CC=C1</smiles>

(c: retroisosterism)<smiles>[R]OC([R])=O</smiles>

Fig. 2. Examples of non-classical bioisosteres.

Макед. фарм. билт., 66 (2) 15 - 33 (2020) 
Table 4. Examples of bioisosteric replacement in drug development

Drug (Replacement)<smiles>O=C(O)c1cn(C23CC4CC(C4)C2C3)c2cc(N3CCNCC3)c(F)cc2c1=O</smiles>

Ciprofloxacin (Bayer, 1983)<smiles>CCn1cc(C(=O)O)c(=O)c2cc(F)c(N3CCNCC3)cc21</smiles>

Norfloxacin (Kyorin, 1979)

Cipro is about 10 times as potent as norfloxacin. It is far more successful. It is one of the most commonly prescribed drugs and had earned Bayer about 2 billion euros as at 2001 (Prochilo 2013; Wise et al., 1983)

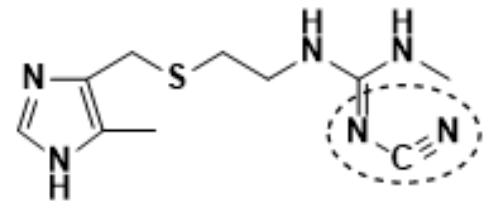

Cimetidine<smiles>CNC(=S)NCCSCc1nc[nH]c1C</smiles>

Metiamide

Cimetidine is free from the side effects (nephrotoxicity and agranulocytosis) which limited the clinical use of metiamide (ACS, 1997)

Bioisosterism has been widely applied in drug design to achieve improved selectivity, fewer side effects, decreased toxicity, improved pharmacokinetics, increased metabolic stability, simplified synthetic routes, patented novel compounds, and development of analogues of therapeutic innovations (me-tooism). Few examples of the successful application of bioisosteres in drug development are shown in Table 4. Given the vast amounts of bioactivity data and chemoinformatics resources now available, many in silico approaches are now available to mine and identify bioisosteric replacements for fragments of candidate molecules and to evaluate candidate molecules against simulated biological targets. A thorough review of the wide variety of computational approaches to bioisosterism has been published (Papadatos and Brown, 2013).

\section{Physiological importance of blood pressure and hypertension}

Blood pressure, the pressure exerted by the blood upon the walls of the arteries and veins, is vital to maintaining normal function in the body. Adequate blood pressure is essential to ensuring that all parts of the body are supplied with blood - the vital fluid that sustains them. To be adequate, not only does blood pressure have to be high enough to flow rapidly throughout the body, but it needs to change quickly to accommodate the body's needs (Patlak, 2003). Normal blood pressure in an adult is approximately $120 \mathrm{mmHg}$ systolic and $80 \mathrm{mmHg}$ diastolic; often abbreviated as $120 / 80 \mathrm{mmHg}$ (Whelton et al., 2018). High blood pressure or hypertension, defined as blood pressure being persistently above $130 / 90$ or $140 / 90$ $\mathrm{mmHg}$, poses a major health risk. It affects $16-37 \%$ of the population globally and in 2010 was reported to have been a factor in $18 \%$ of all deaths globally (Campbell et al., 2015; Poulter et al., 2015).

However, it was not until the middle of the 20th century that elevated blood pressure was recognized as a serious health problem. Prior to this time it was merely regarded as a benign consequence of aging. By this time, researchers had uncovered that hypertension often fosters other cardiovascular diseases (such as heart attacks, strokes, heart failure and aneurysm) and kidney failure (Kannel et al., 1961; Patlak, 2003). These findings indicated the need for development of drugs for treating hypertension. However, progress could not be made in this regard until scientists gained a better understanding of how the body controls blood pressure. 
Renin-angiotensin system (RAS) and angiotensinconverting enzyme (ACE) as drug targets

The inception of the discovery of the reninangiotensin system and its role in hypertension was in 1898 when Tigerstedt and Bergman found that saline extracts of kidney contained a vasopressor which they named renin (Tigerstedt and Bergman, 1898). Following many years of extensive studies into physiology of blood pressure regulation and pathophysiology of hypertension, by the 1960s, the renin-angiotensin system (RAS) had been elucidated and its major functions described. The renin-angiotensin system (RAS) or the reninangiotensin-aldosterone system (RAAS) is a hormone system that regulates blood pressure, fluid and electrolyte balance, and systemic vascular resistance (Fountain and Lappin, 2019).

In response to a decrease in blood pressure, juxtaglomerular cells in the kidneys are activated; converting prorenin into renin and releasing renin into the blood stream. Renin, a protease, then hydrolyzes angiotensinogen, a circulating protein released by the liver, to produce a physiologically inactive decapeptide, angiotensin I. Subsequently, angiotensin I is cleaved by the angiotensin-converting enzyme (ACE), a dipeptidylcarboxypeptidase found mainly in the lungs, to angiotensin II, an octapeptide (Fig. 3). Angiotensin II binds to its receptors causing vasoconstriction, which results to an increase in blood pressure (Yee et al., 2010). Angiotensin II also stimulates the secretion of aldosterone, a hormone involved in the regulation of blood volume and sodium and potassium balance (Ghosh and Gemma, 2014). Aldosterone increases the reabsorption of sodium ions by the renal tubules, leading to increase in retention of water and increase in blood volume, which contributes in increasing blood pressure.

The discovery and description of the reninangiotensin system presented several ready targets, such as renin and ACE, for the development of drugs for treating hypertension. However, the impetus for development of ACE inhibitors as anti-hypertensive agents came from an unusual source.

\section{Snake venom isolate as lead to $\mathrm{ACE}$ inhibitors}

Workers in banana plantations of south-western Brazil were repeatedly reported to collapse suddenly after being bitten by a pit viper, Bothrops jararaca. This aroused the curiosity of Mauricio Rocha e Silva, a biomedical scientist at a Brazilian research institute, who began to study the effects of the venom of $B$. jararaca in dogs and guinea pigs. In 1948, Rocha e Silva discovered a peptide in animal blood plasma incubated with venom of the Brazilian pit viper (Hagwood, 1997). The peptide, which was found to dilate blood vessels and responsible for the hypotensive effect and circulatory shock induced by the venom, was named bradykinin. In the mid-1960s, one of Rocha e Silva's students, Sergio Ferreira, for his $\mathrm{PhD}$ thesis isolated a factor from the snake venom. This factor demonstrated vasodilation effect by raising bradykinin levels in the blood and he termed it bradykinin potentiating factor (BPF) (Ferreira, 1965). Subsequently,

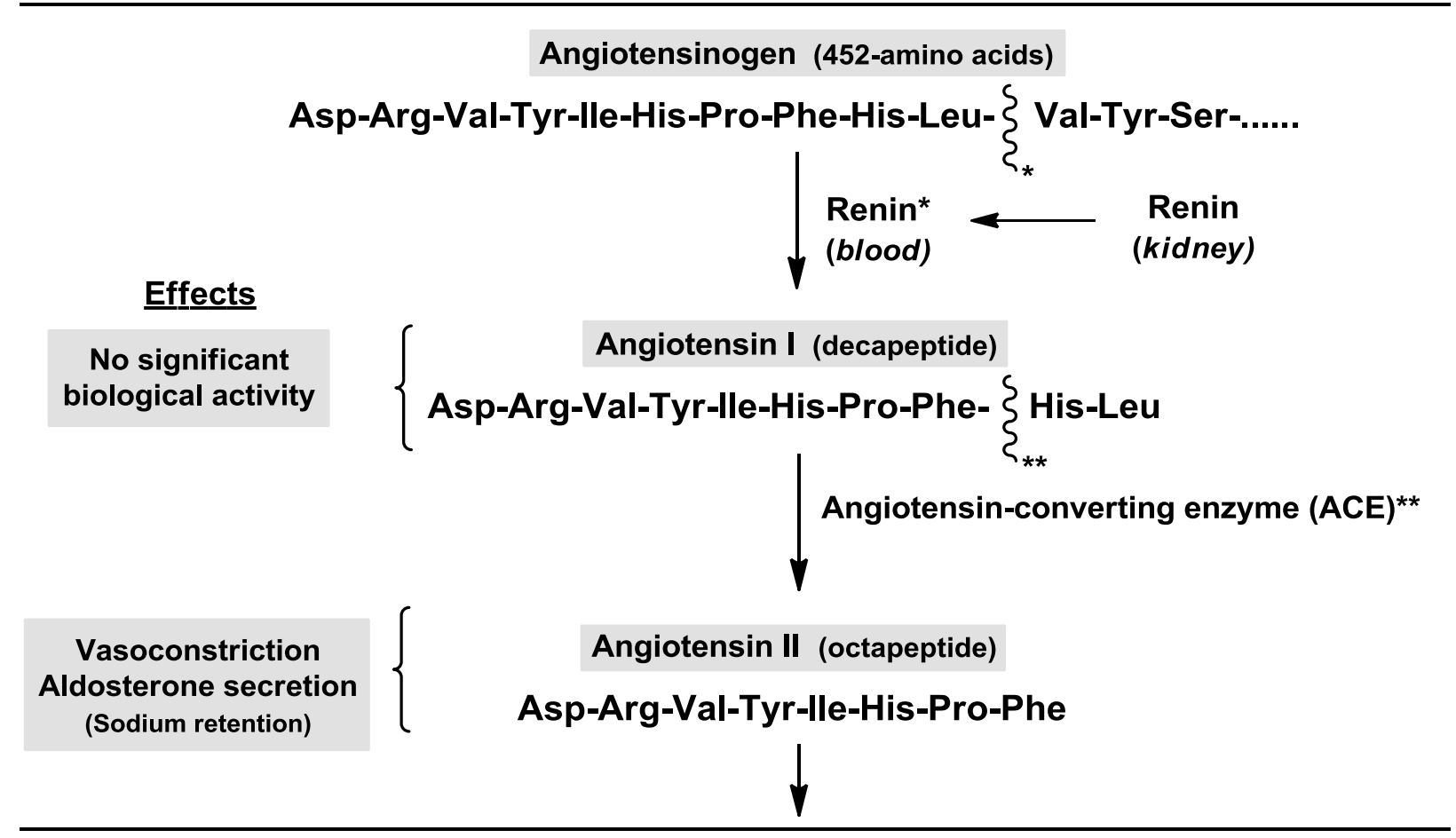

Fig. 3. Simplified illustration of the renin-angiotensin system (RAS).

Макед. фарм. билт., 66 (2) 15 - 33 (2020) 
Ferreira traveled to London with the snake venom to work as a post-doc in the lab of Sir John Vane (awarded the Nobel Prize in Physiology or Medicine in 1982), a pharmacologist at the Royal College of Surgeons. Vane, immersed in studies of angiotensin I and II, and ACE at the time, enthusiastically suggested to Ferreira to examine his BPF on the renin-angiotensin system (Vane, 1999). Ferreira however chose to continue his work on bradykinin. Few years later, Vane and his other colleagues eventually tested BPF on the renin-angiotensin system and showed that BPF inhibited the conversion of angiotensin I to angiotensin II (Aiken and Vane, 1970; Bakhle, 1968). In 1970, now convinced that ACE inhibition was important, Ferreira and his team isolated nine peptides from BPF and they called them bradykinin potentiating peptides (BPPs) (Ferreira et al., 1970a). BPPs were shown to not only induce bradykinin potentiation but also inhibit angiotensin I conversion (Ferreira et al., 1970b), thus indicating the parallelism between both activities and corroborating the findings of Vane's team. Two out of the nine peptides $\left(\mathrm{BPP}_{9 \mathrm{a}}\right.$ and $\left.\mathrm{BPP}_{5 \mathrm{a}}\right)$ were considered for further studies; for separate reasons. $\mathrm{BPP}_{9 \mathrm{a}}$ (later called teprotide), a nonapetide, was the most active, while $\mathrm{BPP}_{5 \mathrm{a}}$, a pentapeptide (Fig.4a), was the smallest, indicating easier synthesis and characterization. Recognizing the pharmacological potentials of the snake venom and its isolates, Vane, who was then a consultant for the U.S. pharmaceutical company Squibb (now Bristol-Myers Squibb), suggested to researchers at Squibb to study the snake venom and its isolates for their effects on the reninangiotensin system and possibly as leads for the development of novel drugs for the treatment of hypertension (Vane, 1999).

\section{Pyr-Lys-Trp-Ala-Pro $\left(\mathbf{a}: \mathbf{B P P}_{5 \mathrm{a}}\right)$}

\section{Glu-Trp-Pro-Arg-Pro-GIn-Ile-Pro-Pro (b: $\mathrm{BPP}_{9 \mathrm{a}}$ or Teprotide)}

Fig. 4. Amino acid sequences of $\mathrm{BPP}_{5 \mathrm{a}}$ and $\mathrm{BPP}_{9 \mathrm{a}}$ or teprotide.

Vane's suggestion was not received with much enthusiasm; scientists at Squibb noted that a peptide drug would be susceptible to metabolic deactivation by peptidases and inactive orally. However, eventually a biochemist and a peptide chemist at Squibb, David Cushman and Miguel Ondetti embarked on the project. They sequenced $\mathrm{BPP}_{9 \mathrm{a}}$ (Fig.4b) and established that it is a potent ACE inhibitor and also made a synthetic version called SQ 20,881 or teprotide after its four proline residues (Cheung and Cushman, 1973; Ondetti et al., 1971). However, as they had predicted, teprotide was poorly absorbed and susceptible to metabolic deactivation by peptidases in the gut. Following this development, they tinkered with the compound but all the resulting compounds failed abysmally (Patlak, 2003). During this time between 1970 and 1973 scientists at Squibb randomly screened about 2000 compounds in their lab to see if they too might inhibit ACE, but except for a few metal binding compounds and other nonspecific agents, the exercise was almost completely in vain (Ondetti et al., 1982). These failures and frustrations led to the abandonment of the project at the time.

\section{Structure-based drug design and development of Captopril}

In 1966, a chemist at Harvard University, William Lipscomb (awarded the Nobel Prize in Chemistry in 1976) used X-ray crystallography to determine the threedimensional structure of carboxypeptidase A, a pancreatic enzyme. Four years later, Lipscomb published the detailed structure and mechanism of the enzymatic activity of the enzyme (Lipscomb, 1970). In the early 1970s, Larry Byers and Richard Wolfenden at University of North Carolina reported L-benzyl succinic acid as a potent inhibitor of carboxypeptidase A. They noted the structural similarities between L-benzyl succinic acid and the substrate and by-products of the catalytic action of the enzyme. Owing to this observation, they proposed a concept of "by-product analogue" inhibitor design and designed other inhibitors of carboxypeptidase A that mimicked the structures of the by-products of the peptidolytic action of the enzyme (Byers and Wolfenden, 1972; 1973).

Following this series of events, Cushman and Ondetti at Squibb noted the similarities between the properties of carboxypeptidase A and ACE (a dipeptidylcarboxypeptidase whose structure had not been determined then, in fact, it was not until 2003 that the first human ACE structure was reported by Natesh et al.). They speculated that ACE has an active site similar to that of carboxypeptidase A, presumably including the presence of a zinc ion, as reported in the structure of carboxypeptidase A (Cushman and Ondetti, 1991). They opined that the major difference between the two carboxypeptidases was that the active site of ACE had evolved to accommodate a dipeptide residue rather than a single amino acid residue of the peptidolytic action of carboxypeptidase A. They subsequently resumed their search for ACE inhibitors. They rationalized their search by developing hypothetical model of the active site of ACE and proposed a hypothetical template for its inhibitors (Fig. 5). 


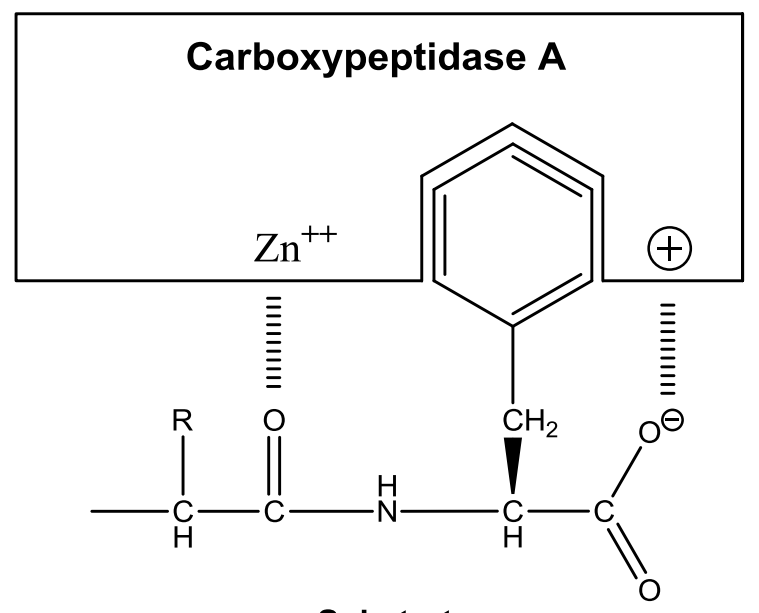

Substrate

(a)

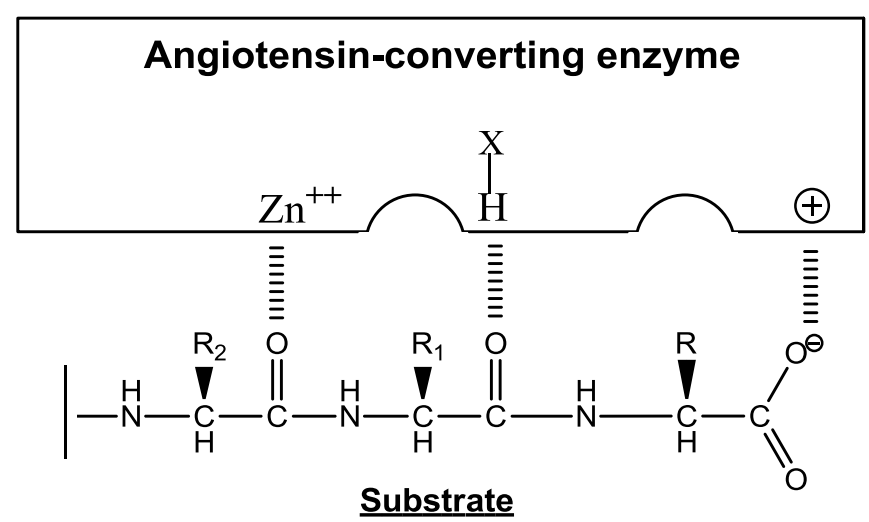

(b)

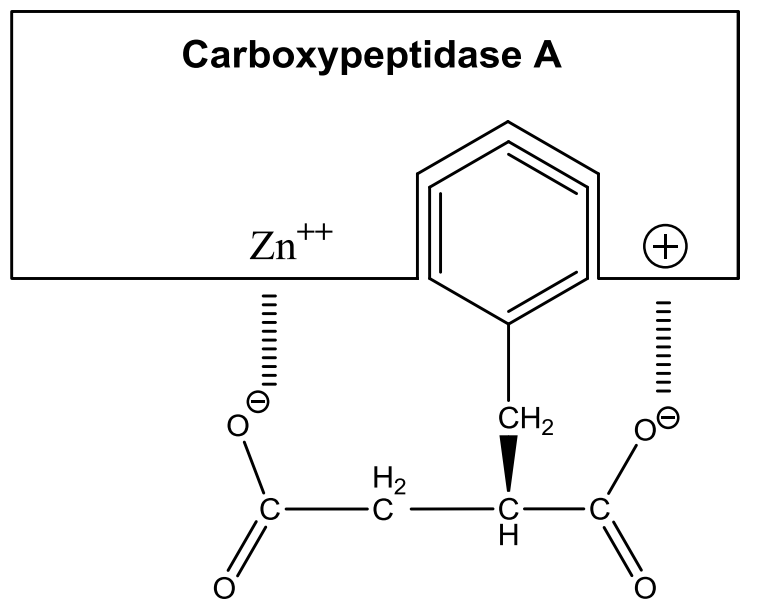

L-benzyl succinic acid (Inhibitor)

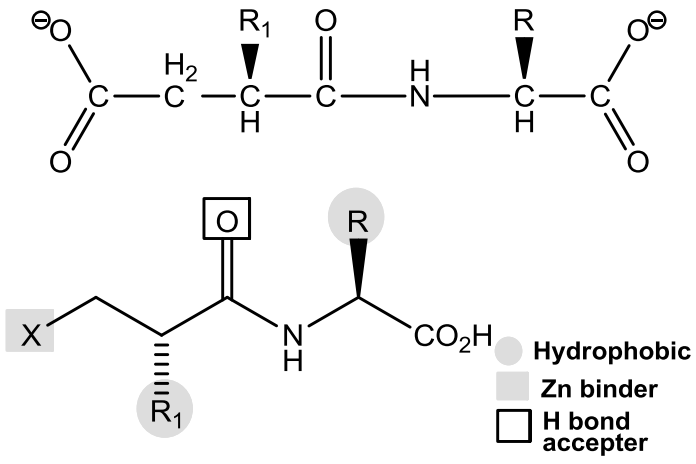

Proposed inhibitors

Fig. 5. Schematic illustration of (a) the binding of substrate and inhibitor at the active site of carboxypeptidase A; (b) the hypothetical model of ACE and its substrate and template of its proposed inhibitors (adapted from Cushman et al., 1977).

The chemists at Squibb systematically modified their hypothetical template and made a series of derivatives (Fig. 6) which were tested as ACE inhibitors. They found that the compound that gave the best activity was succinyl-L-proline (Fig. 6d), which retains the proline terminal unit of their first lead-teprotide (Cushman et al., 1977).

Though succinyl-L-proline gave the best activity of the tested compounds (Fig. 6), its activity was still not as high as required for an effective drug. In fact, it was only about $1 / 500$ as potent as teprotide, thus necessitating further modification (Cushman et al., 1977). The carboxylic group at $\mathrm{C} 3$, responsible for binding to the zinc ion on the enzyme, was identified for modification and this led to search for better alternative groups. Isosteric exchanges with amine, amide, guanidine and sulfhydryl were considered. The sulfhydryl function yielded the compound succinyl-L-proline sulfide (Fig. 7b), a potent inhibitor that was about 1600 times more active than
succinyl-L-proline.

Further development involved optimization of the acyl side chain (Fig. 8). Chain extension by increase in methylene $\left(-\mathrm{CH}_{2}-\right)$ group from 2 to 3 gave 4mercaptoalkanoyl derivative (Fig. 8c), which was about 50 times less potent. Similarly, chain contraction by decrease in methylene $\left(-\mathrm{CH}_{2}-\right)$ group from 2 to 1 yielded 2-mercaptoalkanoyl derivative (Fig. 8a) with 5 times reduction in activity. However, insertion of methyl group $\left(-\mathrm{CH}_{3}\right)$ group at $\mathrm{C} 2$ of the acyl side chain gave the compound SQ 14,225 (Fig. 8d), a 2-methyl-3mercaptopropanoyl derivative which was about 10 times more potent. SQ 14,225 was found to be the most potent inhibitor of all the compounds tested and Squibb introduced it as captopril (marketed as Capoten) in April 1981, about a decade after the commencement of the project. The discovery and development of captopril, the first marketed, orally active ACE inhibitor, was a breakthrough and among the earliest successes of the 
<smiles>CC(C)C[C@H](N)C(=O)CCC(=O)O</smiles>

(a: Succinyl-L-leucine)

$\mathrm{IC}_{50}=610 \mu \mathrm{M}$<smiles>N=C(N)NCCC[C@H](N)C(=O)CCC(=O)O</smiles>

(c: Succinyl-L-arginine)

$\mathrm{IC}_{50}=470 \mu \mathrm{M}$<smiles>O=C(O)CCC(=O)N[C@H](Cc1ccccc1)C(=O)O</smiles>

(b: Succinyl-L-phenylalanine) $\mathrm{IC}_{50}=550 \mu \mathrm{M}$<smiles>CCCCCCC(=O)N1CCC[C@H]1C(=O)O</smiles>

(d: Succinyl-L-proline)

$\mathrm{IC}_{50}=330 \mu \mathrm{M}$

Fig. 6. Structures of succinyl-L-proline and few other succinyl derivatives tested against ACE.

revolutionary and innovative concept of structure-based drug design, which takes into account the enzyme structure and molecular interactions to guide drug development (it has to be emphasized here that through the entirety of the project, which culminated in the discovery of captopril, the structure of ACE had not been fully characterized, the design approach by the Squibb's team was largely conjectural). For this feat, Cushman and Ondetti were awarded the Lasker Award in 1999 and designated "Heroes of Chemistry" by the American Chemical Society in 2000. They were also inducted into the National Inventors Hall of Fame in 2007.

\section{The development and design of other ACE inhibitors}

Cushman et al. (1982) noted that “...captopril is a very simple chemical structure with at least five welldefined chemical interactions with the active site of ACE". It is apparent however that the simplicity of captopril does not incorporate all the possible competitive interactions with ACE; thus, allowing further optimization and development of subsequent ACE inhibitors. In addition, following its approval and clinical introduction, captopril was observed to be associated with rashes, metallic or loss of taste, and proteinuria (Atkinson and Robertson, 1979). It was also reported to have a relatively poor pharmacokinetic profile, its short half-life necessitating 2-3 per day dosing, which portends poor treatment adherence. These side effects and pharmacokinetic limitations also stimulated the modification of captopril and development of subsequent ACE inhibitors. The modifications have mainly involved replacement of the sulfhydryl function and/or varying the amino acid backbone.<smiles>O=C(O)CCC(=O)N1CCC[C@H]1C(=O)O</smiles>

(a: Succinyl-L-proline)

$\mathrm{IC}_{50}=330 \mu \mathrm{M}$

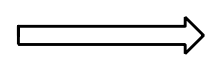

$\mathrm{IC}_{50}=0.2 \mu \mathrm{M}$

Fig. 7. Development of succinyl-L-proline sulfide (application of functional group isosterism to lead optimization). 


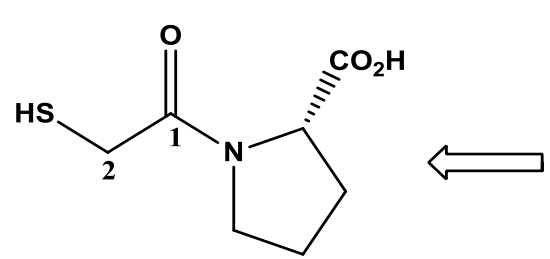

(a: $\left.\mathrm{IC}_{50}=1.1 \mu \mathrm{M}\right)$<smiles>O=C(O)[C@@H]1CCCN1C(=O)CCS</smiles>

(b: $\left.\mathrm{IC}_{50}=0.2 \mu \mathrm{M}\right)$

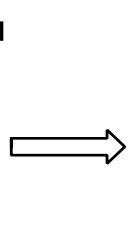

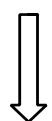<smiles></smiles>

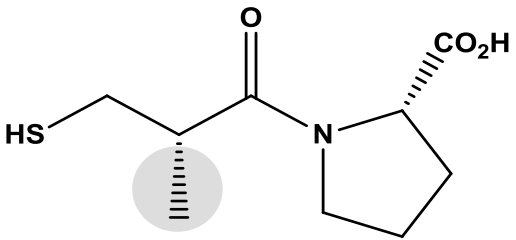

(d: SQ $14,225, \mathrm{IC}_{50}=0.023 \mu \mathrm{M}$ )<smiles>O=C(O)[C@@H]1CCCN1C(=O)CCCS</smiles>

(c: $\left.\mathrm{IC}_{50}=9.7 \mu \mathrm{M}\right)$

(Captopril)

Fig. 8. Development of captopril, (modification of chain length and substituent for lead optimization).

\section{Development of enalapril}

Enalapril was the first ACE inhibitor introduced after captopril. It was developed partly to overcome the limitations and optimize the ACE inhibitory activity of captopril. Medicinal chemists at Merck Research Laboratories speculated that the sulfhydryl group was responsible for the aforementioned side effects, since such side effects were also known with the sulfhydrylcontaining chelator penicillamine, which Merck markets for Wilson's disease (Patchett, 2002). They hypothesized that replacing the sulfhydryl group might attenuate the side effects as well as increase metabolic stability. Initial modification involved isosteric replacements of the sulfhydryl group (-SH) with a carboxylate function $\left(\mathrm{HOOCCH}_{2}-\right)$ and the methylene $\left(-\mathrm{CH}_{2}-\right)$ group at $\mathrm{C} 3$ of the acyl side chain with an amine function $(-\mathrm{NH}-)$ to afford a dipeptide (Ala-Pro) derivative (Fig. 9b). This dicarboxylate compound however was less potent than captopril; this was suspected to be due to the increased polarity and hydrophilicity (Patchett et al., 1980). To compensate for this, a methyl group $\left(-\mathrm{CH}_{3}\right)$ was inserted at the $\alpha$-carbon to the $\mathrm{N}$-terminal carboxyl group. The resulting derivative (Fig. 9c) was more potent than the previous compound but still less potent than captopril. Systematic exploration of hydrophobic substituents at this position revealed that larger groups are more favourable. Insertion of a phenethyl function afforded the compound enalaprilat (Fig. 9d), which was about 20 times more potent than captopril and without the side effects that limited the latter (Patchett et al., 1980). However, enalaprilat had poor oral bioavailability (Ulm, 1983). To overcome this, the N-terminal carboxyl group was esterified to obtain enalapril (Fig. 9e), a prodrug that is deesterified in vivo to the active form, enalaprilat. Enalapril (marketed as Vasotec) was introduced by Merck in December 1985; and it became Merck's first billion dollar-selling drug in 1988 (Li, 2013).

\section{Development of other dicarboxylate ACE inhibitors}

Subsequent to the clinical success of enalapril, other dicarboxylate ACE inhibitors (Fig. 10) were developed. They were specifically developed with enalapril (or enalaprilat) as the lead compound. The first of these compounds was developed by Merck's scientists. It was obtained from systematic exploration of amino acid functions at each position in enalaprilat. Replacement of the methyl group $\left(-\mathrm{CH}_{3}\right)$ at $\mathrm{C} 2$ of the acyl side chain with a lysyl function $\left(-\left(\mathrm{CH}_{2}\right)_{4} \mathrm{NH}_{2}\right)$ gave lisinopril, which had comparable potency to enalaprilat. Lisinopril is more hydrophilic, but surprisingly, it has good oral bioavailability (Patchett, 1993), thus not a prodrug unlike others in this group and was introduced by Merck in 1987. The next was cilazapril (introduced by HoffmannLa Roche), which was the first ACE inhibitor drug without the proline unit. Cilazapril inspired other lipophilic ACE inhibitor prodrugs such as, ramipril (Hoechst AG, now Aventis), benazepril (Novartis), perindopril (Servier) and trandolapril (Abbott) which involved an expansion of the proline unit into a bicyclic system. Modification of ring size is an important strategy in lead optimization. The principle behind this strategy is that expansion or contraction of a ring system may slightly adjust the angles and relative positions of the neighboring atoms and groups, which could lead to better interactions with specific regions in the binding site of the target. This can be understood by considering a series of 


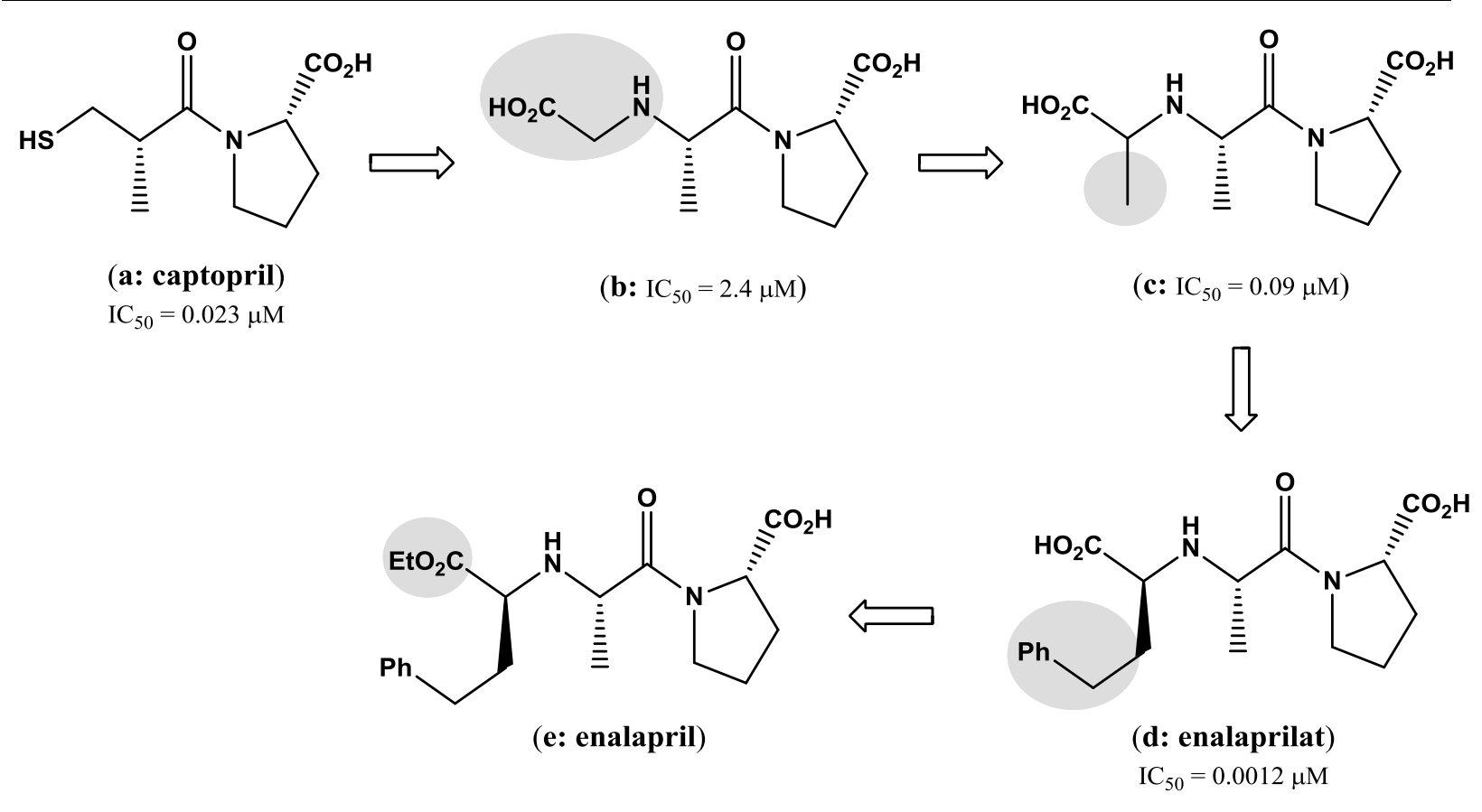

Fig. 9. Development of enalapril.

monocyclic lactam analogues of enalaprilat developed by Merck's scientists (Fig. 11). For these compounds, an almost 4000-fold increase in activity was observed in passing from the five-membered to the eight-membered homologue (Thorsett et al., 1986; Wermuth, 2006), indicating the dramatic increase in ligand-target affinity impacted by the ring expansion. Furthermore, it is a wellknown rule of thumb in drug design that enlarging a molecule or incorporation of bulky groups often confer rigidity and usually improves selectivity. This could explain the improved potencies of the dicarboxylate ACEinhibitors with bicyclic systems. The rank order of potency of different ACE-inhibitors has been investigated in different biological assays and reported as: benazeprilat $>$ ramiprilat > perindoprilat > lisinopril > enalaprilat > fosinoprilat $>$ captopril (Dzau et al., 2001).<smiles>NCCCC[C@H](N[C@@H](CCc1ccccc1)C(=O)O)C(=O)N1CCC[C@H]1C(=O)O</smiles>

(a: Lisinopril)<smiles>CCOC(=O)[C@H](CCc1ccccc1)N[C@H]1CCc2ccccc2N(CC(=O)O)C1=O</smiles>

(d: Benazepril)<smiles>CCOC(=O)[C@H](CCc1ccccc1)N[C@H]1CCCN2CCC[C@H](C(=O)O)N2C1=O</smiles>

(b: Cilazapril)<smiles>CCC[C@H](N[C@@H](C)C(=O)N1[C@H](C(=O)O)C[C@@H]2CCCC[C@H]21)C(=O)OCC</smiles>

(e: Perindopril)<smiles>CCOC(=O)[C@H](CCc1ccccc1)N[C@@H](C)C(=O)N1[C@H](C(=O)O)C[C@@H]2CCC[C@H]21</smiles>

(c: Ramipril)<smiles>CCOC(=O)[C@H](CCc1ccccc1)N[C@@H](C)C(=O)N1[C@H](C(=O)O)C[C@H]2CCCC[C@H]21</smiles>

(f: Trandolapril)

Fig. 10. Structures of some other dicarboxylate ACE inhibitors. 


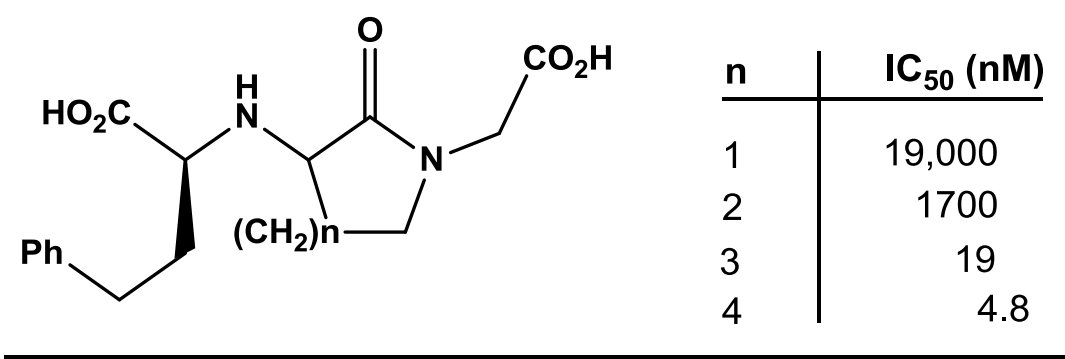

Fig. 11. Development of lactam analogues of enalaprilat (modification of ring size for lead optimization).

Here, a docking study was conducted on some ACEinhibitors to evaluate their binding affinities against human testis ACE protein (tACE) (PDB ID: 1UZF, Natesh et al., 2004). The results (Table 5) show that the expanded molecules have higher binding affinities compared to captopril. The binding affinity is in the order: fosinoprilat $>$ cilazaprilat $>$ benazeprilat $=$ ramiprilat $>$ enalaprilat > perindoprilat > lisinopril > zofenoprilat > captopril. As shown in Fig. 12, the sulfhydryl group of captopril interacts with the catalytic zinc ion; it further anchors the ligand to the protein through a series of pisulfur interactions with HIS-353, HIS-383 and TYR-523 residues. The carboxylate and carbonyl groups of captopril also interact with GLN-281 and HIS-353, respectively, through hydrogen bond formation. A couple of pi-alkyl interactions was observed between the methylene group at the 3-position of captopril's proline unit and HIS-383 and TYR-523 residues. Interestingly, these computed binding interactions are similar to those obtained by Natesh et al. (2004) from experimentally cocrystallized ACE-captopril complex and those originally hypothesized by Cushman et al. (1977) in their design approach. For the dicarboxylate ACE inhibitors, the second carboxylate function shows similar interactions to those of the sulfhydryl group of captopril. As shown in Fig. 13, the carboxylate group of cilazaprilat interacts with HIS-353, just like the sulfhydryl in captopril; it however forms additional hydrogen bond with HIS-513. The other carboxylate group further binds the ligand to the protein through a series of hydrogen bonds with ASN-277, GLU-376 and GLN-281 residues. Furthermore, the phenyl group affords a pair of pi-pi Tshaped interactions with PHE-457 and PHE-527.

\section{Development of other sulfhydryl ACE inhibitors}

In order to optimize the ACE inhibitory activity of captopril, medicinal chemists at Squibb subjected captopril to structural modifications (Krapcho et al., 1988). Systematic exploration of lipophilic alkyl and aromatic substituents at the 4-position of the pyrrolidine ring led to the insertion of a phenyl sulfanyl group ( $\mathrm{PhS}-$ ), giving the compound zofenoprilat (Fig. 14b), which demonstrated greater ACE inhibitory activity. However, like captopril, zofenoprilat has unfavourable oral pharmacokinetic profile. This was identified to be due to the free sulfhydryl group on the side chain. Protection of this group with a benzoyl unit (PhCO-) afforded the prodrug, zofenopril (Fig. 14c), a more lipophilic and potent drug with longer duration of action but with similar rash forming and irritative taste propensity as captopril.

Table 5. Molecular docking analysis of some ACE-inhibitors on human testis ACE protein (tACE)

\begin{tabular}{|c|c|c|}
\hline Compound & $\begin{array}{l}\text { Binding Affinity } \\
(\mathrm{kcal} / \mathrm{mol})\end{array}$ & Docking Materials and Conditions \\
\hline Fosinoprilat & -9.4 & - $3 D$-structure of tACE protein (PDB ID: IUZF): www.rcsb.org \\
\hline Cilazaprilat & -8.8 & - 3D-structure of ligands: PubChem database \\
\hline Benazeprilat & -8.5 & - Protein and ligand preparations: Discovery Studio Visualizer \\
\hline Ramiprilat & -8.5 & $(\mathrm{DSV})^{*}$, AutoDock Tools ${ }^{\#}$ \\
\hline Enalaprilat & -8.4 & - Protein-ligand docking: AutoDock Vina ${ }^{\dagger}$ \\
\hline Perindoprilat & -8.0 & - Grid box dimension: size $(\AA): 40$ x 44 x 118; center $(\AA)$ : \\
\hline Lisinopril & -7.7 & 40.473 x 37.237 x $43.429 ;$ spacing $(\AA): 0.506$ \\
\hline Zofenoprilat & -7.4 & - Exhaustiveness: 100 \\
\hline Captopril & -5.7 & - Visualization and analysis of results: DSV \\
\hline
\end{tabular}

Макед. фарм. билт., 66 (2) 15 - 33 (2020) 

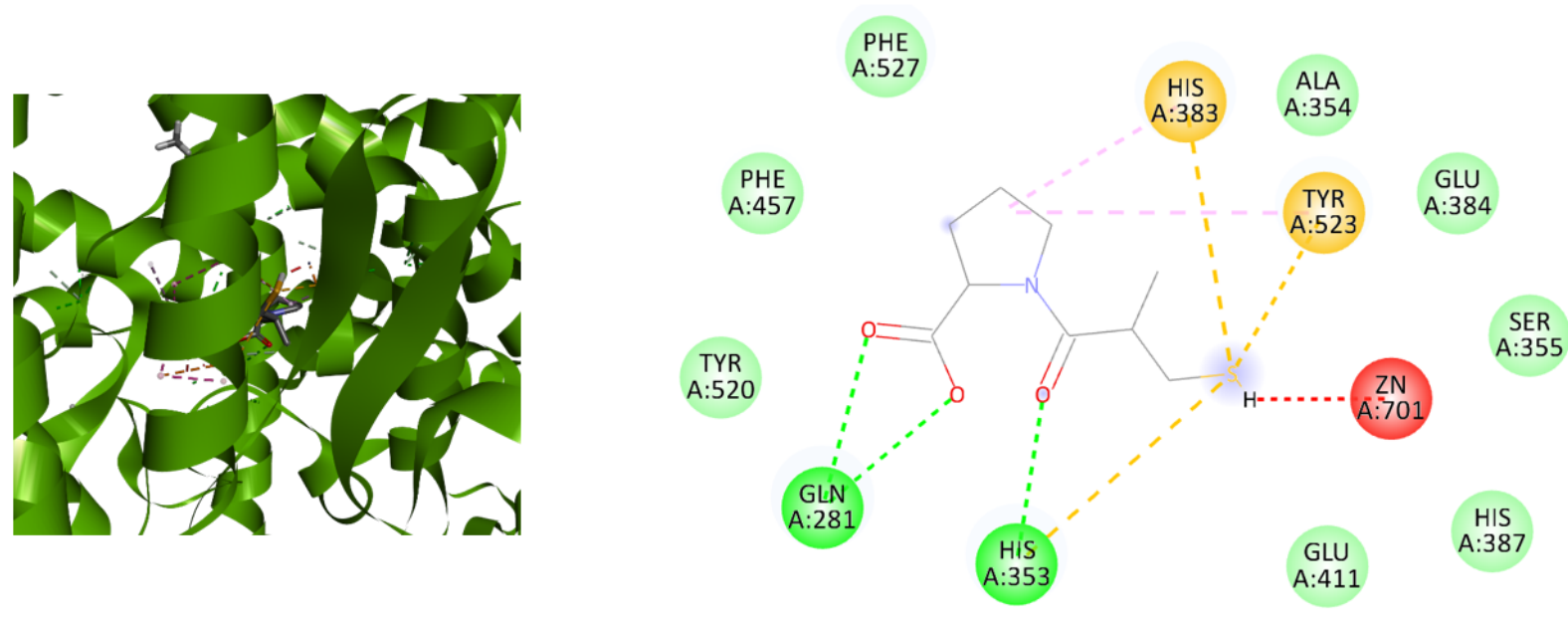

\section{Interactions}

Fig. 12. $3 \mathrm{D}$ and $2 \mathrm{D}$ diagrams of ligand-protein interaction of captopril and tACE showing the protein surface, ligand structure and the interacting residues and atoms.

Similar modifications involving the sulfhydryl and/or proline functions led to the development of other sulfanyl ACE inhibitors such as fentiapril, pivalopril and alacepril (Fig. 15).

\section{Development of phosphinate ACE inhibitors}

The development of phosphinate ACE inhibitors started from the observation of the hypotensive effects of phosphoramidon, a secondary metabolite isolated from the bacterium Streptomyces tanashiensis (Suda et al., 1973). Phosphoramidon was found to be a potent inhibitor of ACE and ECE (endothelin converting enzyme involved in the proteolytic release of endothelin 1,2 and 3, which are prohypertensive vasoconstricting peptides) (Petrillo et al., 1983). Phosphoramidon, a glycopeptide, contains a phosphoramide linkage between an L-rhamnose glycone and an L-leucine-Ltryptophan dipeptide (Fig. 16a). A study using crystal structures of thermolysin and

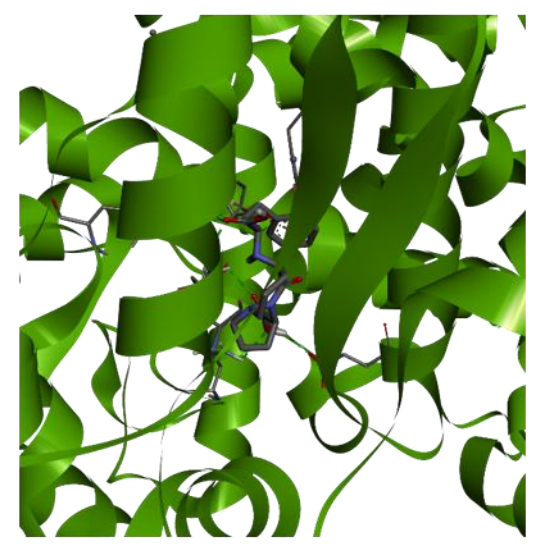

Interactions

van der Waals

Conventional Hydrogen Bond

Pi-Pi T-shaped

Fig. 13. 3D and 2D diagrams of ligand-protein interaction of cilazaprilat and tACE showing the protein surface, ligand structure and the interacting residues and atoms. 


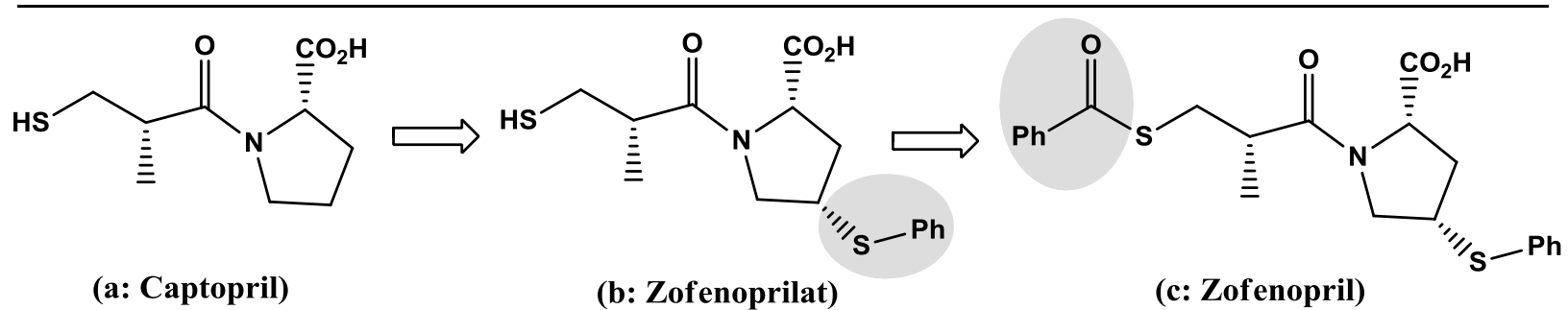

Fig. 14. Development of zofenopril.

carboxypeptidase A revealed that the phosphinyl moiety in phosphoramidon mediates its binding to the $\mathrm{Zn}^{2+}$ in these enzymes (Kam et al., 1979). Scientists speculated that this moiety could mediate similar function against ACE. These findings inspired medicinal chemists at Squibb to attempt to develop ACE inhibitors containing the phosphinate function. Applying the concepts employed in the development of zofenoprilat and enalaprilat they developed the compound fosinoprilat (Fig. 16c) (Krapcho et al., 1988). Fosinoprilat demonstrated the desired potency but proved to have the same shortcoming as enalaprilat, poor oral bioavailability. Further development involving the protection of the phosphinate hydroxyl group with a hydrophobic group to mitigate the ionization propensity of the molecule led to a prodrug, fosinopril (Fig. 16d) (DeForrest et al., 1989), currently the only phosphinate-containing ACE inhibitor in clinical use.

Among the ACE-inhibitors used for the docking study against tACE, fosinoprilat has the highest binding affinity, giving a binding energy of $-9.4 \mathrm{kcal} / \mathrm{mol}$ (Table 5). As shown in Fig. 17, the phosphinyl moiety largely mediates the binding of the ligand to the active site of the protein. It interacts strongly with GLN-281, LYS-511 and HIS-513 residues through hydrogen bonds. It further interacts with HIS-353 and TYR-523. The carboxylate group of the proline unit forms additional interactions through hydrogen bonds with ASN-277 and THR-282. Furthermore, the phenyl extension shows a pair of pialkyl interactions with VAL-379 and VAL-380. A couple of hydrophobic interactions was also observed between the cyclohexyl group and VAL-380 and ALA-354 residues.<smiles>O=C(O)[C@@H]1CSC(c2ccccc2O)N1C(=O)CCS</smiles>

(a: Fentiapril)<smiles>C[C@H](CSC(=O)C(C)(C)C)C(=O)N(CC(=O)O)C1CCCC1</smiles>

(b: Pivalopril)<smiles>CC(=O)SC[C@H](C)C(=O)N1CCC[C@H]1C(=O)N[C@@H](Cc1ccccc1)C(=O)O</smiles>

(c: Alacepril)

Fig. 15. Structures of some other sulfanyl ACE inhibitors.

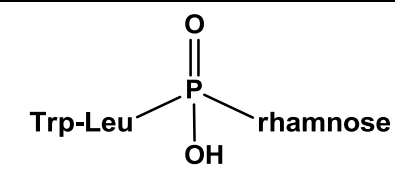

(a: Phosphoramidon)<smiles>CCOC(=O)[C@H](CCc1ccccc1)N[C@@H](C)C(=O)N1CCC[C@H]1C(=O)O</smiles>

(b: Enalapril)

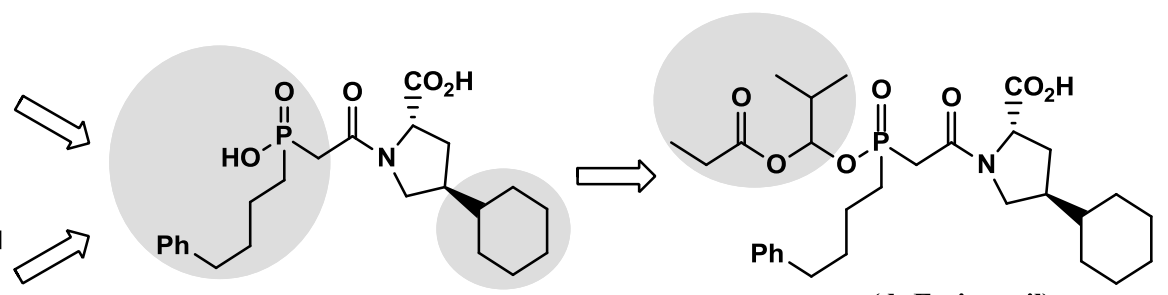

(c: Fosinoprilat) (d: Fosinopril)

Fig. 16. Development of fosinopril. 


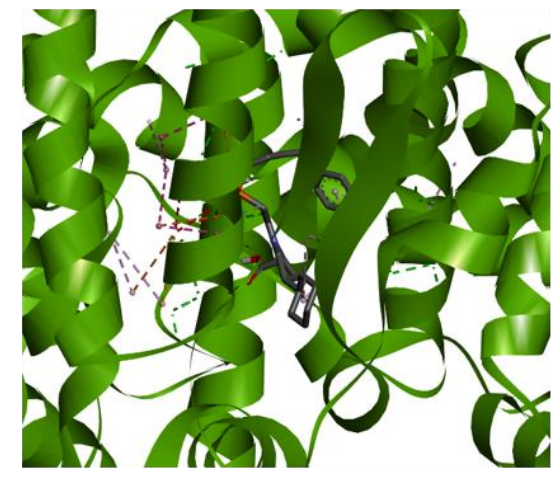

Interactions

van der Waals

Conventional Hydrogen Bond

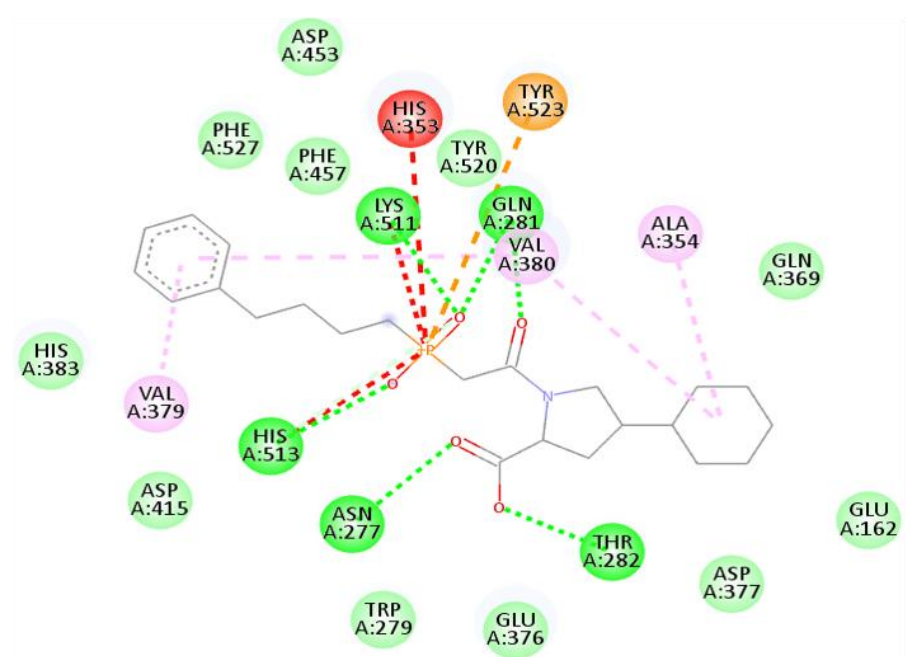

Fig. 17. 3D and 2D diagrams of ligand-protein interaction of fosinoprilat and tACE showing the protein surface, ligand structure and the interacting residues and atoms.

\section{Other natural product ACE inhibitors}

Since the report of the ACE inhibitory activity of teprotide and other peptides isolated from the Brazilian pit viper's venom, there has been a continuous search for novel inhibitors of ACE from natural sources. Peptides have received special attention in this regard; this could be attributed to the crucial role that snake venom peptide played in the discovery and development of the first clinically approved ACE inhibitor and the growing interest in nutraceuticals and functional foods. Presently, hundreds of peptides with antihypertensive activity have been reported. Recently, a database, AHTPDB, was developed, which systematically catalog about 6000 antihypertensive (mostly ACE inhibitory) peptides along with their properties (Kumar et al., 2015). Some of the most potent ACE inhibitory peptides reported are presented in Table 6. It is proposed to present here, only the sequences, sources and $\mathrm{IC}_{50}$ values; further details may be found by reference to the original papers. Out of these peptides, the short chain sequences have received considerable attention due to the fact that they are less affected by proteolytic degradation by the gastrointestinal enzymes when orally ingested and are easily absorbed and, therefore, bioavailable (Aluko, 2008; Kitts and Weiler, 2003; Yuan and Kitts, 1991). Examples are the well-known lactotripeptides, Ile-Pro-Pro (IPP) and ValPro-Pro (VPP), which are structurally similar to the first peptide ACE inhibitor, teprotide (Fig. 18). Several studies have been carried out to evaluate the clinical importance of the lactotripeptides in the management of hypertension; these studies however have produced conflicting results.

\section{Glu-Trp-Pro-Arg-Pro-GIn-Ile-Pro-Pro}

(a: Teprotide)

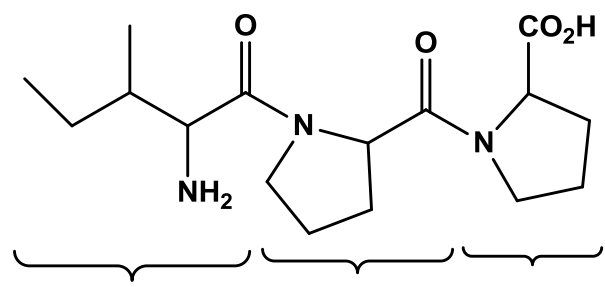

(b: Ile-Pro-Pro)

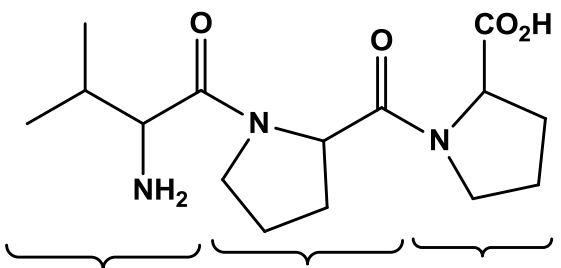

(c: Val-Pro-Pro)

Fig. 18. Similarity in the sequences of IPP, VPP and teprotide. 
Table 6. Some peptides from natural sources showing ACE inhibitory activities

\begin{tabular}{llll}
\hline \hline Peptide & Source & $\mathrm{IC}_{50}(\mu \mathrm{M})$ & Reference \\
\hline VVYPWTQRF & Oyster mantle & 0.066 & Ketnawa and Rawdkuen (2013) \\
VSV & Rapeseed & 0.15 & Wu et al. (2008) \\
IKW & Chicken muscle & 0.21 & Fujita et al. (2000) \\
LRW & Pea & 0.23 & Gu et al. (2011) \\
LRP & Maize & 0.27 & Miyoshi et al. (1991) \\
LKP & Chicken muscle & 0.32 & Fujita et al. (2000) \\
VVYPW & Bullfrog muscle & 0.36 & Sagardia et al. (2012) \\
LRIPVA & Spinach & 0.38 & Yang et al. (2003) \\
FFGVRCVSP & Egg proteins & 0.4 & Majumder and Wu (2010) \\
FFGRCVSP & Egg proteins & 0.4 & Gu et al. (2011) \\
GHKIATFQER & Baker's yeast & 0.4 & Kohama et al. (1990) \\
FTDVDFIK & Sweet-potato & 0.42 & Huang et al. (2011) \\
IVY & Wheat gliadin & 0.48 & García et al. (2013) \\
FKGRYYP & Chicken muscle & 0.55 & Fujita et al. (2000) \\
MRW & Spinach & 0.6 & Yang et al. (2003) \\
IRW & Egg proteins & 0.6 & Gu et al. (2011) \\
IRY & Egg proteins & 0.6 & Majumder and Wu (2010) \\
RYLGY & Casein & 0.71 & Contreras et al. (2009) \\
LKY & Sesame & 0.78 & García et al. (2013) \\
MAP & Cheese & 0.8 & Puchalska et al. (2015) \\
\hline
\end{tabular}

$\mathrm{IC}_{50}$ : concentration of peptide capable of inhibiting $50 \%$ of ACE activity

These results have been further analysed in six published meta-analyses. Five of these meta-analyses (Cicero et al., 2010; 2013; Pripp, 2008; Turpeinen et al., 2013; Xu et al., 2008) concluded that the lactotripeptides have hypotensive effects in pre-hypertensive and hypertensive subjects and could therefore be applied as a supplement or alternative to pharmaceutical treatment for mild hypertension. However, Usinger et al. (2012) in their meta-analysis opined that the evidence is not sufficient to suggest that the lactotripeptides could be a successful intervention in pre-hypertensive and hypertensive subjects. Nevertheless, in several countries, including USA, Spain, Japan, Finland, Switzerland, Iceland, UK, and Italy, products enriched with lactotripeptides are available in the market as blood pressure-lowering agents (Warensjo et al., 2010).

\section{Conclusion}

The ACE inhibitors were introduced primarily as antihypertensive agents. Subsequently they were found to be useful for other cardiovascular and kidney diseases (Jackson, 2006). Today, the ACE inhibitors have not only become established as cornerstones in the treatment of the entire continuum of cardiovascular diseases, including hypertension, stable coronary artery disease, myocardial infarction and heart failure, and diabetic neuropathy, they have also substantially improved the prognosis of patients with these conditions (Borer, 2007). The account of the development of the ACE inhibitors reflects the compounding effects of basic and collaborative research in scientific breakthroughs. And as the case of the statins (Oladipupo et al., 2019), it highlights the rigorous research and great amounts of time and resources often needed to nurture a lead compound or concept to a clinically approved drug. In addition, the development of the first ACE inhibitor initiated a new era of structurebased or rational drug design that has subsequently been applied successfully for development of drugs for many other disorders, including HIV and cancer.

\section{Acknowledgement}

This manuscript was originally prepared as a lecture in Drug Discovery, Design and Development course. The author is grateful to his academic mentor, Distinguished Prof. H.A.B. Coker, for stimulating the conception of the idea of this paper. 


\section{References}

ACS: American Chemical Society, 1997. National Historic Chemical Landmarks. Tagamet $\AA$ : Discovery of Histamine H2-receptor Antagonists. Available at: http://portal.acs.org/portal/PublicWebSite/education/whati schemistry/landmarks/cimetidinetagamet/index.htm (Last accessed: July 10, 2020).

Aiken, J.W., Vane, J.R., 1970. The renin-angiotensin system: inhibition of converting enzyme in isolated tissues. Nature 228, 30-34. Available at: https://doi.org/10.1038/228030a0.

Atkinson, A.B., Robertson, J.I., 1979. Captopril in the treatment of clinical hypertension and cardiac failure. Lancet 2(8147), 836-839. Available at: https://doi.org/10.1016/s0140-6736(79)92186-X.

Bakhle, Y.S., 1968. Conversion of angiotensin I to angiotensin II by cell-free extracts of dog lung. Nature 220, 919-921. Available at: https://doi.org/10.1038/220919a0.

Barreiro, E.J., Fraga, C.A.M., 2001. Química Medicinal: As Bases Moleculares da Ação dos Fármacos, first ed. ArtMed Ltda., Porto Alegre, RS, pp. 163.

BIOVIA, 2021. BIOVIA Discovery Studio Visualizer, 21.1.0.0. Dassault Systèmes, San Diego.

Borer, J.S., 2007. Angiotensin-converting enzyme inhibition: a landmark advance in treatment for cardiovascular diseases. Eur. Heart J. Suppl. 9(Supplement E), E2-E9. Available at: https://doi.org/10.1093/eurheartj/sum037.

Burger, A., 1991. Isosterism and bioisosterism in drug design. Prog. Drug Res. 37, 288-362. Available at: https://doi.org/10.1007/978-3-0348-7139-6_7.

Burger, A., 1970. Medicinal Chemistry, third ed. WileyInterscience, New York, pp. 64-80.

Byrd, J.B., Ram, C.V.S., Lerma, E.V., 2019. Pharmacologic treatment of hypertension, in: Lerma, E.V., Sparks, M., Topf, J. (Eds.), Nephrology Secrets, fourth ed. Elsevier, pp. 477-482. Available at: https://doi.org/10.1016/b978-0323-47871-7.00078-2.

Byers, L.D., Wolfenden, R., 1972. A potent reversible inhibitor of carboxypeptidase A. J. Biol. Chem. 247, 606-608.

Byers, L.D., Wolfenden, R., 1973. Binding of the by-product analog benzylsuccinic acid by carboxypeptidase A. Biochemistry 12, 2070-2078. Available at: https://doi.org/10.1021/bi00735a008.

Campbell, N.R., Lackland, D.T., Lisheng, L., Niebylski, M.L., Nilsson, P.M., Zhang, X.H., 2015. Using the Global Burden of Disease study to assist development of nationspecific fact sheets to promote prevention and control of hypertension and reduction in dietary salt: a resource from the World Hypertension League. J. Clin. Hypertens. 17(3), 165-167. Available at: https://doi.org/10.1111/jch.12479.

Cheung, H.S., Cushman, D.W., 1973. Inhibition of homogeneous angiotensin-converting enzyme of rabbit lung by synthetic venom peptides of Bothrops jararaca. Biochim. Biophys. Acta 293, 451-463. Available at: https://doi.org/10.1016/0005-2744(73)90352-5.

Cicero, A.F.G., Aubin, F., Azais-Braesco, V., Borghi, C., 2013. Do the lactotripeptides isoleucine-proline-proline and valine-proline-proline reduce systolic blood pressure in european subjects? A meta-analysis of randomized controlled trials. Am. J. Hypertens. 26, 442-449. Available at: https://doi.org/10.1093/ajh/hps044.

Cicero, A., Gerocarni, B., Laghi, L., Borghi, C., 2010. Blood pressure lowering effect of lactotripeptides assumed as functional foods: a meta-analysis of current available clinical trials. J. Hum. Hypertens. 25, 425-436. Available at: https://doi.org/10.1038/jhh.2010.85.

Contreras, M., Carrón, R., Montero, M.J., Ramos, M., Recio, I., 2009. Novel casein-derived peptides with antihypertensive activity. Int. Dairy J. 19(10), 566-573. Available at: https://doi.org/10.1016/j.idairyj.2009.05.004.

Cushman, D.W., Ondetti, M.A., 1991. History of the design of captopril and related inhibitors of angiotensin converting enzyme. Hypertension 17, 589-592. Available at: https://doi.org/10.1161/01.hyp.17.4.589.

Cushman, D.W., Cheung, H.S., Sabo, E.F., Ondetti, M.A., 1977. Design of potent competitive inhibitors of angiotensin-converting enzyme. Carboxyalkanoyl and mercaptoalkanoyl amino acids. Biochemistry 16(25), 5484-5491. Available at: https://doi.org/10.1021/bi00644a014.

Cushman, D.W., Cheung, H., Sabo, E.F., Ondetti, M.A., 1982. Development and design of specific inhibitors of angiotensin-converting enzyme. Am. J. Cardiol. 49, 13901394. Available at: https://doi.org/10.1016/00029149(82)90348-4.

DeForrest, J.M., Waldron, T.L., Scalese, B., Rubin, B., Powell, J.R., Petrillo, E.W., Cushman, D.W., 1989. Fosinopril a phosphinic acid inhibitor of angiotensin I converting enzyme; in vitro and preclinical in vivo pharmacology. J. Cardiovasc. Pharmacol. 14, 730-736. Available at: https://doi.org/10.1097/00005344-198911000-00009.

Dzau, V.J., Bernstein, K., Celermajer, D., Cohen, J., Dahlöf, B., Deanfield, J., Diez, J., Drexler, H., Ferrari, R., van Gilst, W., Hansson, L., Hornig, B., Husain, A., Johnston, C., Lazar, H., Lonn, E., Lüscher, T., Mancini, J., Mimran, A., Pepine, C., Rabelink, T., Remme, W., Ruilope, L., Ruzicka, M., Schunkert, H., Swedberg, K., Unger, T., Vaughan, D., Weber, M., Working Group on Tissue Angiotensin-converting enzyme, International Society of Cardiovascular Pharmacotherapy., 2001. The relevance of tissue angiotensin-converting enzyme: manifestations in mechanistic and endpoint data. Am. J. Cardiol. 88(9A), 1L-20L. Available at: https://doi.org/10.1016/s00029149(01)01878-1.

Erlenmeyer, H., Leo, M., 1932. On pseudoatoms. Helv. Chim. Acta $15,1171-1186$. Available at: https://doi.org/10.1002/hlca.193201501132.

Ferreira, S.H., 1965. A bradykinin-potentiating factor (BPF) present in the venom of bothrops jararaca. Br. J. Pharmacol. Chemother. 24(1), 163-169. Available at: https://doi.org/10.1111/j.1476-5381.1965.tb02091.x.

Ferreira, S.H., Bartelt, D.C., Greene, U., 1970a. Isolation of bradykinin-potentiating peptides from Bothrops jararaca venom. Biochemistry 9, 2583-2593. Available at: https://doi.org/10.1021/bi00815a005.

Ferreira, S.H., Greene, L.J., Alabaster, V.A., Bakhle, Y.S. Vane, J.R., 1970b. Activity of various fractions of bradykinin potentiating factor against angiotensin I converting enzyme. Nature 225, 379-380. Available at: https://doi.org/10.1038/225379a0.

Fountain, J.H., Lappin, S.L., 2019. Physiology, ReninAngiotensin System. StatPearls Publishing, Treasure Island (FL). Available at:

https://www.ncbi.nlm.nih.gov/books/NBK470410/ (Last accessed: July 10, 2020). 
Friedman, H.L., 1951. Influence of isosteric replacements upon biological activity, in: First Symposium on ChemicalBiological Correlation, May 26-27, 1950. The National Academies Press, Washington, DC, pp. 295-358. Available at: https://doi.org/10.17226/18474.

Fujita, H., Yokoyama, K., Yoshikawa, M., 2000. Classification and Antihypertensive Activity of Angiotensin I-Converting Enzyme Inhibitory Peptides Derived from Food Proteins. J. Food Sci. 65(4), 564-569. Available at: https://doi.org/10.1111/j.1365-2621.2000.tb16049.x.

García, M.C., Puchalska, P., Esteve, C., Marina, M.L., 2013. Vegetable foods: a cheap source of proteins and peptides with antihypertensive, antioxidant, and other less occurrence bioactivities. Talanta 106, 328-349. Available at: https://doi.org/10.1016/j.talanta.2012.12.041.

Ghosh, A.K., Gemma, S., 2014. Structure-based Design of Drugs and Other Bioactive Molecules: Tools and Strategies, first ed. Wiley-VCH Verlag GmbH \& Co. KGaA, Weinheim. Available at: https://doi.org/10.1002/9783527665211.

Grimm, H.G., 1925. On construction and sizes of non-metallic hydrides. Zeitschrift fur Elektrochemie und Angewandte Physikalische Chemie 31, 474-480.

Gu, Y., Majumdar, K., Wu, J., 2011. QSAR-aided in silico approach in evaluation of food proteins as precursors of ACE inhibitory peptides. Food Res. Int. 44(8), 2465-2474. Available at: https://doi.org/10.1016/j.foodres.2011.01.051.

Hagwood, B.J., 1997. Mauricio Rocha e Silva MD: snake venom, bradykinin and the rise of autopharmacology. Toxicon 35(11), 1569-1580. Available at: https://doi.org/10.1016/s0041-0101(97)00008-1.

Huang, G., Chen, H., Susumu, K., Wu, J., Hou, W., Wu, C., Sheu, M., Huang, S., Lin, Y., 2011. Sweet potato storage root thioredoxin h2 and their peptic hydrolysates exhibited angiotensin converting enzyme inhibitory activity in vitro. Bot. stud. 52(1), 15-22.

Jackson, E.K., 2006. Chapter 30. Renin and Angiotensin, in: Brunton, L.L., Lazo, J.S., Parker, K. (Eds.), Goodman \& Gilman's The Pharmacological Basis of Therapeutics, eleventh ed. McGraw-Hill, New York.

Kam, C.M., Nishino, N., Powers, J.C., 1979. Inhibition of thermolysin and carboxypeptidase A by phosphoramidates. Biochemistry 18(14), 3032-3038. Available at: https://doi.org/10.1021/bi00581a019.

Kannel, W.B., Dawber, T.R., Kagan, A., Revotskie, N., Stokes, J., 1961. Factors of risk in the development of coronary heart disease-six year follow-up experience: The Framingham Study. Ann. Intern. Med. 55, 33-50. Available at: https://doi.org/10.7326/0003-4819-55-1-33.

Ketnawa, S., Rawdkuen, S., 2013. Purification and Characterization of Ace Inhibitory Peptide from Aquatic Resources: A Review. Int. J. Pl. An. and Env. Sci. 3, 220233.

Kohama, Y., Nagase, Y., Oka, H., Teramoto, T., Murayama, N., Tsujibo, H., Inamori, Y., Mimura, T., 1990. Production of angiotensin-converting enzyme inhibitors from baker's yeast glyceraldehyde-3-phosphate dehydrogenase. J. Pharmacobiodyn. 13(12), 766-771. Available at: https://doi.org/10.1248/bpb1978.13.766.

Krapcho, J., Turk, C., Cushman, D.W., Powell, J.R., DeForrest, J.M., Spitzmiller, E.R., Karanewsky, D.S., Duggan, M., Rovnyak, G., Schwartz, J., Natarajan, S., Godfrey, J.D., Ryono, D.E., Neubeck, R., Atwa K.S., Petrillo, E.W., 1988.
Angiotensin-converting enzyme inhibitors. Mercaptan, carboxyalkyl dipeptide, and phosphinic acid inhibitors incorporating 4-substituted prolines. J. Med. Chem. 31(6), 1148-1160. Available at: https://doi.org/10.1021/jm00401a014.

Kumar, R., Chaudhary, K., Sharma, M., Nagpal, G., Chauhan, J.S., Singh, S., Gautam, A., Raghava, G.P.S., 2015. AHTPDB: a comprehensive platform for analysis and presentation of antihypertensive peptides. Nucleic Acids Res. 43, D956-D962. Available at: https://doi.org/10.1093/nar/gku1141.

Langmuir, I., 1919. Isomorphism, isosterism and covalence. J. Am. Chem. Soc. 41, 1543-1559. Available at: https://doi.org/10.1021/ja02231a009.

Larsen, A.A., Lish, P.M., 1964. A new bio-isostere: alkylsulphonamidophenethanolamines. Nature 203, 1283. Available at: https://doi.org/10.1038/2031283a0.

Li, J.J., 2013. History of Drug Discovery, in: Li, J.J., Corey, E.J. (Eds.), Drug Discovery: Practices, Processes, and Perspectives. John Wiley \& Sons, Hoboken, NJ, pp. 1-42. Available at: https://doi.org/10.1002/9781118354483.ch1.

Lima, L.M., Barreiro, E.J., 2005. Bioisosterism: a useful strategy for molecular modification and drug design. Curr. Med. Chem. 12, 23-49. Available at: https://doi.org/10.2174/0929867053363540.

Lipscomb, W., 1970. Structure and mechanism in the enzymatic activity of Carboxypeptidase A and relations to chemical sequence. Acc. Chem. Res. 3, 81-89. Available at: https://doi.org/10.1021/ar50027a001.

Majumder, K., Wu, J., 2010. A new approach for identification of novel antihypertensive peptides from egg proteins by QSAR and bioinformatics. Food Res. Int. 43(5), 13711378. Available at: https://doi.org/10.1016/j.foodres.2010.04.027.

Miyoshi, S., Ishikawa, H., Kaneko, T., Fukui, F., Tanaka, H., Maruyama, S., 1991. Structures and activity of angiotensinconverting enzyme inhibitors in an alpha-zein hydrolysate. Agric. Biol. Chem. 55(5), 1313-1318. Available at: https://doi.org/10.1271/bbb1961.55.1313.

Morris, G.M., Huey, R., Lindstrom, W., Sanner, M.F., Belew, R.K., Goodsell, D.S., Olson, A.J., 2009. AutoDock4 and AutoDockTools4: Automated docking with selective receptor flexibility. J. Comput. Chem. 30(16), 2785-2791. https://doi.org/10.1002/jcc.21256.

Natesh, R., Schwager, S.L.U., Sturrock, E.D., Acharya, K.R., 2003. Crystal structure of the human angiotensinconverting enzyme - lisinopril complex. Nature 421, 551554. Available at: https://doi.org/10.1038/nature01370.

Natesh, R., Schwager, S.L.U., Evans, H.R., Sturrock, E.D., Acharya, K.R., 2004. Structural details on the binding of antihypertensive drugs captopril and enalaprilat to human testicular angiotensin I-converting enzyme. Biochemistry 43, 8718-8724. Available at: https://doi.org/10.1021/bi049480n.

Oladipupo, A.R., Coker, H.A.B., Alaribe, C.S., Okoko, O.D., 2019. Microbial metabolites and enzymes inhibition in drug discovery and development: A case study of the statins, a class of HMG-CoA Reductase inhibitors. Trop. J. Nat. Prod. Res. 3(4), 99-106. Available at: https://doi.org/10.26538/tjnpr/v3i4.1.

Ondetti, M.A., Cushman, D.W., Rubin, B., 1982. Captopril, in: Bindra, J.S., Lednicer, D. (Eds.), Chronicles of Drug Discovery. John Wiley \& Sons, New York, pp. 1-31. 
Ondetti, M.A., Williams, N.J., Sabo, E.F., Pluscec, J., Weaver, E.R., Kocy, O., 1971. Angiotensin-converting enzyme inhibitors from the venom of Bothrops jararaca: Isolation, elucidation of structure, and synthesis. Biochemistry 10, 4033-4039. Available at: https://doi.org/10.1021/bi00798a004

Papadatos, G., Brown, N., 2013. In silico applications of bioisosterism in contemporary medicinal chemistry practice. WIREs Comput. Mol. Sci. 3(4), 339-354. Available at: https://doi.org/10.1002/wcms.1148.

Patchett, A.A., 2002. Alfred Burger award address in medicinal chemistry. Natural products and design: interrelated approaches in drug discovery. J. Med. Chem. 45(26), 5609-5616. Available at: https://doi.org/10.1021/jm020424z.

Patchett, A.A., 1993. Enalapril and lisinopril, in: Lednicer, D. (Ed.), Chronicles of Drug Discovery. American Chemical Society, Washington, DC, pp. 125-162.

Patchett, A.A., Harris, E., Tristram, E.W., Wyvratt, M.J., Wu, M.T., Taub, D., Peterson, E.R., Ikeler, T.J., ten Broeke, J., Payne, L.G., Ondeyka, D.L., Thorsett, E.D., Greenlee, W.J., Lohr, N.S., Hoffsommer, R.D., Joshua, H., Ruyle, W.V., Rothrock, J.W., Aster, S.D., Maycock, A.L., Robinson, F.M., Hirschmann, R., Sweet, C.S., Ulm, E.H., Gross, D.M., Vassil, T.C., Stone, C.A., 1980. A new class of angiotensinconverting enzyme inhibitors. Nature 288, 280-283. Available at: https://doi.org/10.1038/288280a0.

Patlak, M., 2003. From Viper's venom to drug design: treating hypertension, breakthroughs in bioscience. Federation of American Societies for Experimental Biology (FASEB). Available at:

https://www.faseb.org/Portals/2/PDFs/opa/venom.pdf (Last accessed: July 10, 2020).

Petrillo, E.W., Cushman, D.W., Duggan, M.E., Heikes, J.E., Karanewsky, D.S., Ondetti, M.A., O'Reilly, B., Rovnyak, G.C., Schwartz, J., Spitzmiller, E.R., Wang, N.Y., 1983. Peptides: Structure and Function, in: Hruby, V.J., Rich, D.H. (Eds.), Proceedings of the Eighth American Peptide Symposium; Pierce Chemical Co., Rockford, pp. 541.

Poulter, N.R., Prabhakaran, D., Caulfield, M., 2015. Hypertension. Lancet 386(9995), 801-812. Available at: https://doi.org/10.1016/s0140-6736(14)61468-9.

Pripp, A.H., 2008. Effect of peptides derived from food proteins on blood pressure: a meta-analysis of randomized controlled trials. Food Nutr. Res. 52, 1641. Available at: https://doi.org/10.3402/fnr.v52i0.1641.

Prochilo, D., 2013. Bayer's \$74M Cipro Pay-For-Delay Deal Approved in Calif. Available at: http://law360.com/articles/489579 (Last accessed July 10, 2020).

Puchalska, P., Marina, A.M.L., García, L.M.C., 2015. Isolation and characterization of peptides with antihypertensive activity in foodstuffs. Crit. Rev. Food Sci. Nutr. 55(4), 521-551. Available at: https://doi.org/10.1080/10408398.2012.664829.

Sagardia, I., Roa-Ureta, R.H., Bald, C., 2013. A new QSAR model, for angiotensin I-converting enzyme inhibitory oligopeptides. Food Chem. 136(3-4), 1370-1376. Available at: https://doi.org/10.1016/j.foodchem.2012.09.092.

Suda, H., Aoyagi, T., Takeuchi, T., Umezawa, H., 1973. A thermolysin inhibitor produced by actinomycetes: phosphoramidon. J. Antibiot. 26(10), 621-623. Available at: https://doi.org/10.7164/antibiotics.26.621.
Thornber, C.W., 1979. Isosterism and molecular modification in drug design. Chem. Soc. Rev. 8, 563-580. Available at: https://doi.org/10.1039/cs9790800563.

Thorsett, E.D., Harris, E.E., Aster, S.D., Peterson, E.R., Snyder, J.P., Springer, J.P., Hirshfield, J., Tristram, E.W., Patchett, A.A., Ulm, E.H., Vassil, T.C., 1986. Conformationally restricted inhibitors of angiotensin converting enzyme: synthesis and computations. J. Med. Chem. 29, 251-260. Available at: https://doi.org/10.1021/jm00152a014.

Tigerstedt, R., Bergman, P.G., 1898. Niere und Kreislauf. Skand. Arch. Physiol. 8, 223-271. Available at: https://doi.org/10.1111/j.1748-1716.1898.tb00272.x.

Trott, O., Olson, A.J., 2010. AutoDock Vina: improving the speed and accuracy of docking with a new scoring function, efficient optimization, and multithreading. J. Comput. Chem. 31, 455-461. Available at: https://doi.org/10.1002/jcc.21334.

Turpeinen, A.M., Järvenpää, S., Kautiainen, H., Korpela, R., Vapaatalo, H., 2013. Antihypertensive effects of bioactive tripeptides-a random effects meta-analysis. Ann. Med. 45, 51-56. Available at: https://doi.org/10.3109/07853890.2012.663926.

Ulm, E.H., 1983. Enalapril maleate (MK-421), a potent, nonsulfhydryl angiotensin-converting enzyme inhibitor: absorption, disposition and metabolism in man. Drug Metab. Rev. 14, 99-110. Available at: https://doi.org/10.3109/03602538308991383.

Usinger, L., Reimer, C., Ibsen, H., 2012. Fermented milk for hypertension. Cochrane Database Syst. Rev. 4, CD008118. Available at: https://doi.org/10.1002/14651858.cd008118.pub2.

Vane, J.R., 1999. The History of Inhibitors of AngiotensinConverting Enzyme. J. Physiol. Pharmacol. 50(4), 489498.

Warensjo, E., Nolan, D., Tapsel, L., 2010. Chapter 1 - Dairy Food Consumption and Obesity-Related Chronic Disease, in: Taylor, S.L. (Ed.), Advances in Food and Nutrition Research, Volume 59. Elsevier Inc., pp. 1-41. Available at: https://doi.org/10.1016/s1043-4526(10)59001-6.

Wermuth, C.G., 2006. Analogues as a Means of Discovering New Drugs, in: Fischer, J., Ganellin, C.R. (Eds.), Analogue-based Drug Discovery. Wiley-VCH Verlag GmbH \& Co. KGaA, Weinheim, pp. 1-23. Available at: https://doi.org/10.1002/3527608001.ch1.

Whelton, P.K., Carey, R.M., Aronow, W.S., Casey, D.E., Collins, K.J., Dennison, Himmelfarb, C., DePalma, S.M., Gidding, S., Jamerson, K.A., Jones, D.W., MacLaughlin, E.J., Muntner, P., Ovbiagele, B., Smith, S.C., Spencer, C.C., Stafford, R.S., Taler, S.J., Thomas, R.J., Williams, K.A., Williamson, J.D., Wright, J.T., 2018. 2017 ACC/AHA/AAPA/ABC/ACPM/AGS/APhA/ASH/ASPC/ NMA/PCNA Guideline for the Prevention, Detection, Evaluation, and Management of High Blood Pressure in Adults: A Report of the American College of Cardiology/American Heart Association Task Force on Clinical Practice Guidelines. Hypertension 71(6), e13e115. Available at: https://doi.org/10.1161/hyp.0000000000000065.

Wise, R., Andrews, J.M., Edwards, L.J., 1983. In vitro activity of Bay 09867, a new quinoline derivative, compared with those of other antimicrobial agents. Antimicrob. Agents Chemother. 23 (4), 559-564. Available at: https://doi.org/10.1128/aac.23.4.559. 
Wu, J., Aluko, R.E., Muir, A.D., 2008. Purification of angiotensin I-converting enzyme-inhibitory peptides from the enzymatic hydrolysate of defatted canola meal. Food chem. 111(4), 942-950. Available at: https://doi.org/10.1016/j.foodchem.2008.05.009.

Xu, J., Qin, L., Wang, P., Li, W., Chang, C., 2008. Effect of milk tripeptides on blood pressure: a meta-analysis of randomized controlled trials. Nutrition 24, 933-940. Available at: https://doi.org/10.1016/j.nut.2008.04.004.
Yang, Y., Marczak, E.D., Yokoo, M., Usui, H., Yoshikawa, M., 2003. Isolation and antihypertensive effect of angiotensin Iconverting enzyme (ACE) inhibitory peptides from spinach Rubisco [published correction appears in J. Agric. Food Chem. 51(24), 7226]. J. Agric. Food Chem. 51(17), 48974902. Available at: https://doi.org/10.1021/jf026186y.

Yee, A.H., Burns, J.D., Wijdicks, E.F., 2010. Cerebral salt wasting: pathophysiology, diagnosis, and treatment. Neurosurg. Clin. N. Am. 21(2), 339-352. Available at: https://doi.org/10.1016/j.nec.2009.10.011.

\title{
Откривање и развој на АКЕ инхибитори од змиски отров: од токсин до лек и биоизостеризам во развојот на лекови
}

\author{
Аколаде Р. Оладипипо * \\ Оддел за фармацевтска хемија, Фармаиевтски факултет, Универзитет во Лагос, \\ Кампус на Колеи за Медичина, РМВ 12003, Иди-араба, Лагос, Нигерија
}

Клучни зборови: развој на лекови, АКЕ инхибитори, пептид од змиски отров, биоизостеризам, антихипертензивни агенси

Откривањето на инхибиторите на ангиотензин конвертирачкиот ензим (АКЕ) претставува значајно обележје во пронаоѓањето на лекови и напредок во третманот на хипертензија. Нивното воведување во клиничката пракса доведе до значително зголемување на животниот век кај пациентите со хипертензија. Од друга страна пак, развојот на АКЕ инхибитори иницираше нова ера на структуриран или рационален дизајн на лекови што последователно се применува за развој на лекови за многу други нарушувања. Овој труд претставува извештај за откривањето, дизајнот и развојот на АКЕ инхибиторите од академска гледна точка и истиот би можел да користи како водич за идни истражувања. Трудот ги истакнува пресвртниците и ги опишува предизвиците и стратегиите применети за време на развојот на АКЕ инхибиторите. Исто така, во него детално се прецизирани некои од концептите и сложеноста на откривањето, дизајнот и развојот на овие лекови. 
